\title{
FLUXOS MIGRATÓRIOS INTRAMETROPOLITANOS: O CASO DA REGIÃO \\ METROPOLITANA DE FORTALEZA - 1986/1991, 1995/2000 e 2005/2010
}

Sessão Temática: Dinâmica intra-urbana, migração de retorno e pendularidade

Raíssa Marques Sampaio Sidrim

Bacharela em Ciências Econômicas pela Universidade Regional do Cariri (URCA)

Silvana Nunes de Queiroz

Professora Adjunta do Departamento de Economia da Universidade Regional do Cariri

(URCA) e Coordenadora do Observatório das Migrações no Estado do Ceará

\section{RESUMO}

Quando criada, em 1973, a Região Metropolitana de Fortaleza (RMF) contava com apenas cinco municípios, número que aumentou para quinze em 2010. Devido ao intenso crescimento econômico e populacional, faz-se importante contribuir com a análise da evolução recente dos fluxos migratórios intrametropolitanos da RMF, dado que poucas pesquisas se propuseram a abordar essa questão, ainda mais durante um período tão longínquo (quinquênios de 1986/1991, 1995/2000 e 2005/2010). Os microdados dos Censos Demográficos de 1991, 2000 e 2010, levantados pelo Instituto Brasileiro de Geografia e Estatística (IBGE), são a principal fonte de informações. Os principais resultados mostram que a partir da descentralização da atividade econômica e encarecimento do preço de imóveis no núcleo/capital (Fortaleza), esse município vem perdendo população para as cidades periféricas da RMF, principalmente para Caucaia e Maracanaú. Caucaia se tornou atrativa em virtude da proximidade geográfica e fácil acesso à Fortaleza, construção de conjuntos habitacionais e instalação do Complexo Industrial e Portuário do Pécém (CIPP). Maracanaú, devido à construção de um polo industrial e de conjuntos habitacionais. Nesse contexto, os dois municípios apresentaram os maiores saldos migratórios positivos da RMF, enquanto Fortaleza exibiu saldo migratório negativo durante os três períodos, revelando a nova tendência da RMF, a partir da saída de pessoas do núcleo (Fortaleza) em direção à periferia e o aumento do fluxo migratório periferia-periferia.

Palavras-chave: Migração. Intrametropolitana. Região Metropolitana de Fortaleza.

\section{INTRODUÇÃO}

Fortaleza, capital cearense, começou a exibir mudanças no crescimento do seu tecido urbano-metropolitano desde as duas últimas décadas do século XX, afetando diretamente o arranjo espacial atual da Região Metropolitana de Fortaleza (RMF). Essas mudanças são confirmadas tanto nas transformações das formas espaciais visíveis, como nos indicadores demográficos das cidades que fazem parte da RMF (NOGUEIRA, 2013).

A periferização da população é um processo de distribuição característico dos principais espaços metropolitanos brasileiros. Tal processo, em um movimento desigual e maior que os respectivos núcleos metropolitanos é, em parte, justificado pelas migrações intrametropolitanas, que são marcadas pelo deslocamento populacional dos núcleos em direção às periferias (PINHO; BRITO, 2013). 
Dessa maneira, pretende-se averiguar se a tendência de perda populacional do núcleo em direção à periferia contrabalançada pelo aumento do fluxo entre a periferia-núcleo e, notadamente, periferia-periferia, constatada em outras regiões metropolitanas do Brasil (Baeninger, 1999; Soares, Souza e Brito, 2006; Pinho e Brito, 2013), acontece entre Fortaleza e os municípios que compõe a sua região metropolitana.

Neste contexto, este artigo tem como objetivo geral analisar os fluxos migratórios intrametropolitanos na Região Metropolitana de Fortaleza, durante os quinquênios de 1986/1991, 1995/2000 e 2005/2010. São utilizados os microdados dos Censos Demográficos de 1991, 2000 e 2010, levantados pelo Instituto Brasileiro de Geografia e Estatística (IBGE).

Este artigo está organizado em quatro seções. A seção dois descreve o processo de urbanização e metropolização na Região Metropolitana de Fortaleza, apresentando o seu processo de institucionalização, dinâmica populacional e expansão metropolitana. A seção três trata da análise dos fluxos migratórios intrametropolitanos na RMF, durante os quinquênios de 1986/1991, 1995/2000 e 2005/2010. Na última parte são apresentadas as considerações finais.

\section{URBANIZAÇÃO E METROPOLIZAÇÃO NA REGIÃO METROPOLITANA DE FORTALEZA}

\subsection{INSTITUCIONALIZAÇÃO DA REGIÃO METROPOLITANA DE FORTALEZA}

Uma das nove regiões metropolitanas oficializadas no Brasil pela Lei Complementar Federal de número 14, em 1973, foi a Região Metropolitana de Fortaleza. Primeiramente formada por apenas cinco municípios: Aquiraz, Caucaia, Fortaleza, Maranguape e Pacatuba (Quadro 1). Em 1986, pela Lei Complementar Federal de número 52 do mesmo ano, o município de Maracanaú une-se a composição da RMF, logo após a sua emancipação de Maranguape. Essa primeira formação alavancou o incentivo ao desenvolvimento de polos industriais nos municípios ao redor, fato de significativa importância na construção do atual cenário da RM (TSUKUMO et al., 2013).

\section{Quadro 1: Ano de incorporação e legislação dos municípios que compõem a RMF}

\begin{tabular}{|l|c|c|}
\hline Município & Ano de incorporação & Legislação \\
\hline Aquiraz & Jun 1973 & LCF 14/73 \\
\hline Cascavel & Jun 2009 & LCE 78/09 \\
\hline Caucaia & Jun 1973 & LCF 14/73 \\
\hline Chorozinho & Dez 1999 & LE 18/99 \\
\hline Eusébio & Abr 1991 & LE 11.845 \\
\hline Fortaleza & Jun 1973 & LCF 14/73 \\
\hline
\end{tabular}




\begin{tabular}{|l|c|c|}
\hline Guaiúba & Abr 1991 & LE 11.845 \\
\hline Horizonte & Dez 1999 & LE 18/99 \\
\hline Itaitinga & Dez 1999 & LE 18/99 \\
\hline Maracanaú & Abr 1986 & LCF 52/86 \\
\hline Maranguape & Jun 1973 & LCF 14/73 \\
\hline Pacajus & Dez 1999 & LE 18/99 \\
\hline Pacatuba & Jun 1973 & LCF 14/73 \\
\hline Pindoretama & Jun 2009 & LCE 78/09 \\
\hline São Gonçalo & Dez 1999 & LE 18/99 \\
\hline
\end{tabular}

Fonte: IPECE - Anuário Estatístico do Ceará, 2012

Em 1988, com a nova Constituição Federal, a responsabilidade do Governo Federal criar, alterar e organizar as regiões metropolitanas passou para os Estados. Assim, Guaiuba e Eusébio passaram a fazer parte da RMF em 1991, por meio da Lei Estadual de número 11.845 do mesmo ano. O município de Guaiuba foi separado do município de Pacatuba e Eusébio do município de Aquiraz, os quais já faziam parte da região metropolitana. Em 1999, o município de Itaitinga, desmembrado de Pacatuba, é incorporado à região metropolitana, mediante a Lei Complementar Estadual de número 3/1995 (TSUKUMO et al., 2013).

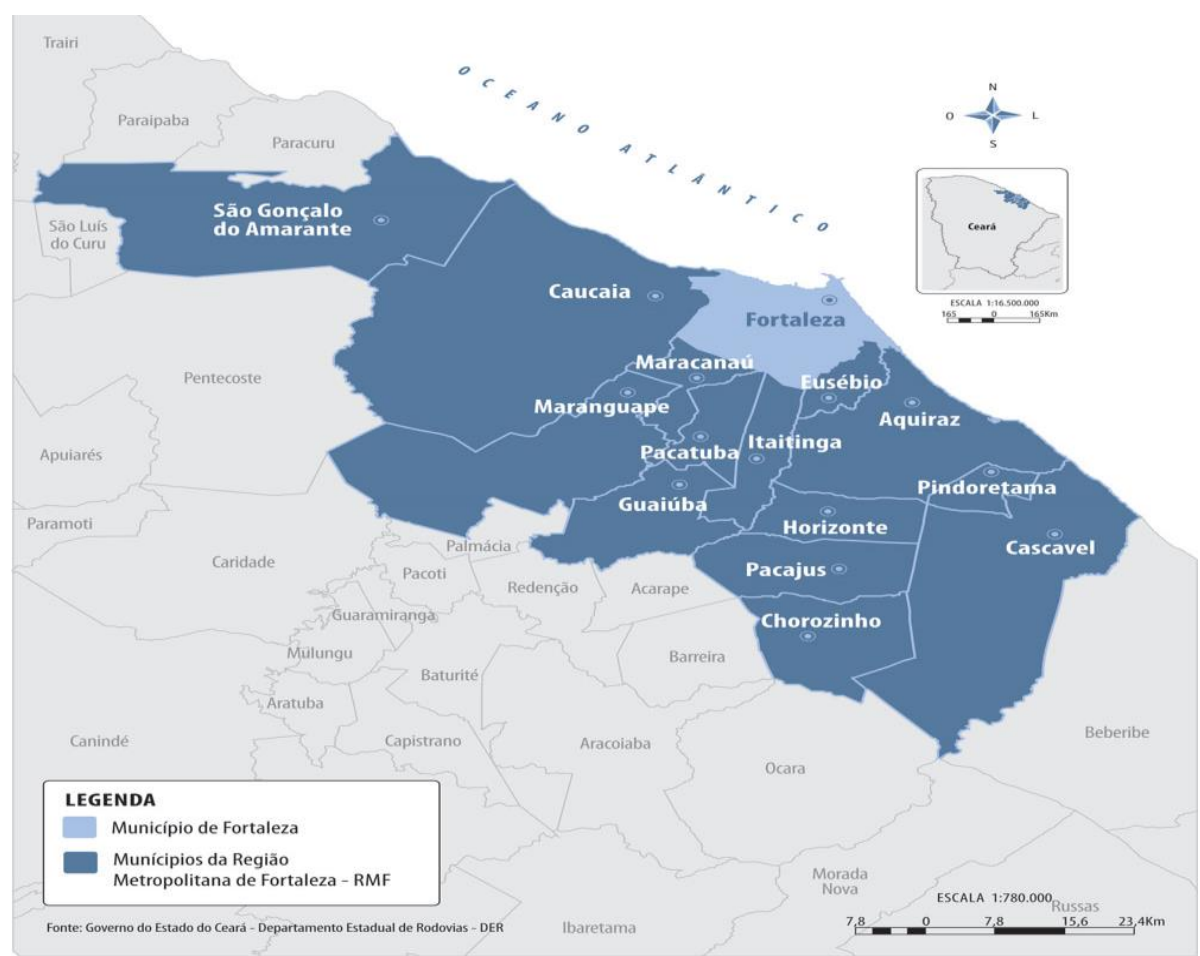

Figura 1 - Localização dos municípios que compõem a RMF

Fonte: Governo do Estado do Ceará - Departamento Estadual de Rodovias - DER. Disponível em: http://www.anuariodefortaleza.com.br/a-cidade/mapa-da-regiao-metropolitana-de-fortaleza.php

Por meio da lei 12.989, os municípios de Horizonte, Pacajus, Chorozinho e São Gonçalo foram introduzidos à região metropolitana no ano de 1999, deixando a RMF com 13 municípios. Segundo Gonçalves (2011, p. 147): “em termos políticos-administrativos, a RMF 
sofreu transformações devido a dois processos: os desmembramentos e a agregação de outros municípios da região.” A atual estrutura da Região Metropolitana de Fortaleza ficou completa em 2009, quando o governo estadual modificou a Lei Complementar 18/1999, no qual agrega à RMF os municípios de Cascavel e Pindoretama (GONÇALVES, 2011).

De acordo com o Artigo $2^{\circ}$ da Lei Complementar Estadual número 18 do ano de 1999, um dos componentes fundamentais para a expansão da Região Metropolitana de Fortaleza é a "evidência ou tendência de conurbação" (Ceará, 1999). Entretanto, quando é feita uma análise histórica da taxa de urbanização, observa-se que a atual formação da região é dona da menor taxa de urbanização, com 96,11\%. Enquanto a formação de 1986 apresenta a maior taxa, com 97,55\%. Isto é, se nos dias atuais a RMF continuasse com somente os seis municípios integrantes em 1986, teria uma taxa de urbanização mais elevada que a recente, mostrando que a expansão da RMF ficou paradoxal com o Artigo 2º da LCE nº18/1999 (TSUKUMO et al., 2013)

\subsection{DINÂMICA POPULACIONAL E EXPANSÃO METROPOLITANA DA RMF}

Em termos populacionais, em 2010, os quinze municípios que compõem a RMF concentram mais de 3,6 milhões de habitantes, em uma área de 5.785,822 km², representando cerca de $43 \%$ do total da população do estado do Ceará (8.448.055 milhões de habitantes) (Tabela 1). A grande maioria dessa população está localizada na cidade de Fortaleza, com 2.452.185 milhões de pessoas, figurando com cerca de $29 \%$ da população estadual. Caucaia aparece como a maior área da RMF, com $1.227 .895 \mathrm{~km}^{2}$, e a segunda maior população (324.441 mil habitantes), seguida de Maracanaú, com 209.057 habitantes. Por outro lado, Pindoretama é o município com a menor área da RMF, com apenas 72,85 km², e também apresenta a menor população, com 18.638 habitantes em 2010.

Tabela 1 - Área $\left(\mathrm{km}^{2}\right)$ e população total - Municípios da Região Metropolitana de Fortaleza - 1980 - 2010

\begin{tabular}{l|c|c|c|c|c|c|c|c|c}
\hline Município & $\begin{array}{c}\text { Área } \\
\left(\mathbf{k m}^{\mathbf{2}}\right)\end{array}$ & $\begin{array}{c}\text { População } \\
\mathbf{( 1 9 8 0 )}\end{array}$ & $\begin{array}{c}\text { Pop. } \\
\mathbf{( \% )}\end{array}$ & $\begin{array}{c}\text { População } \\
\mathbf{( 1 9 9 1 )}\end{array}$ & $\begin{array}{c}\text { Pop. } \\
(\mathbf{\%})\end{array}$ & $\begin{array}{c}\text { População } \\
\mathbf{( 2 0 0 0 )}\end{array}$ & $\begin{array}{c}\text { Pop. } \\
(\mathbf{\%})\end{array}$ & $\begin{array}{c}\text { População } \\
\mathbf{( 2 0 1 0}\end{array}$ & $\begin{array}{c}\text { Pop. } \\
(\mathbf{\%})\end{array}$ \\
\hline Fortaleza & 313,14 & 1.307 .608 & 75,27 & 1.768 .637 & 71,87 & 2.141 .402 & 70,05 & 2.452 .185 & 67,82 \\
\hline Caucaia & $1.227,89$ & 94.106 & 5,42 & 165.099 & 6,71 & 250.479 & 8,19 & 325.441 & 9,00 \\
\hline Maracanaú & 105,69 & 37.894 & 2,18 & 157.151 & 6,39 & 179.732 & 5,88 & 209.057 & 5,78 \\
\hline Maranguape & 590,82 & 91.137 & 5,25 & 71.705 & 2,91 & 88.135 & 2,88 & 113.561 & 3,14 \\
\hline Aquiraz & 480,97 & 45.112 & 2,60 & 46.305 & 1,88 & 60.469 & 1,98 & 72.628 & 2,01 \\
\hline Pacatuba & 132,42 & 42.106 & 2,42 & 60.148 & 2,44 & 51.696 & 1,69 & 72.299 & 2,00 \\
\hline Cascavel & 837,96 & 47.677 & 2,74 & 46.507 & 1,89 & 57.129 & 1,87 & 66.142 & 1,83 \\
\hline Pacajus & 254,43 & 46.981 & 2,70 & 31.800 & 1,29 & 44.070 & 1,44 & 61.838 & 1,71 \\
\hline Horizonte & 159,97 & - & - & 18.283 & 0,74 & 33.790 & 1,11 & 55.187 & 1,53 \\
\hline
\end{tabular}




\begin{tabular}{lccccccccr} 
Eusébio & 78,65 & - & - & 20.410 & 0,83 & 31.500 & 1,03 & 46.033 & 1,27 \\
\hline São Gonçalo & 834,39 & 24.694 & 1,42 & 29.286 & 1,19 & 35.608 & 1,16 & 43.890 & 1,21 \\
\hline Itaitinga & 150,78 & - & - & - & - & 29.217 & 0,96 & 35.817 & 0,99 \\
\hline Guaiuba & 267,2 & - & - & 17.562 & 0,71 & 19.884 & 0,65 & 24.091 & 0,67 \\
\hline Chorozinho & 278,4 & - & - & 154.92 & - & 18.707 & 0,61 & 18.915 & 0,52 \\
\hline Pindoretama & 72,85 & - & - & 12.442 & 0,51 & 14.951 & 0,49 & 18.683 & 0,52 \\
\hline Total & $\mathbf{5 . 7 8 5 , 8 2}$ & $\mathbf{1 . 7 3 7 . 3 1 5}$ & $\mathbf{1 0 0 , 0 0}$ & $\mathbf{2 . 4 6 0 . 8 2 7}$ & $\mathbf{1 0 0 , 0 0}$ & $\mathbf{3 . 0 5 6 . 7 6 9}$ & $\mathbf{1 0 0 , 0 0}$ & $\mathbf{3 . 6 1 5 . 7 6 7}$ & $\mathbf{1 0 0 , 0 0}$ \\
\hline
\end{tabular}

Fonte: Elaboração própria a partir dos microdados dos Censos Demográficos de 1980,1991, 2000 e 2010 IBGE.

Apesar de concentrar, em 1980, 75\% da população da RM, Fortaleza tem diminuído o seu peso relativo, uma vez que, em 2010, atinge cerca de 68\% (Tabela 1). Em termos de crescimento populacional, de 1980 a 1991, quando somente sete municípios faziam parte da Região Metropolitana de Fortaleza, ela cresceu 3,46\% a.a (Tabela 2), com o município de Caucaia apresentando o maior crescimento (5,24\%). De 1991 a 2000, a RMF cresceu a uma taxa de 2,4\% ao ano, enquanto Fortaleza cresceu à uma taxa menor (2,1\% a.a). Por sua vez, os municípios de Horizonte (7,1\%), Eusébio (4,9\%), Caucaia (4,7\%), Pacajus (3,7\%) e Aquiraz $(3,0 \%)$ cresceram mais, enquanto Maranguape (2,3\%), Chorozinho (2,1\%) e São Gonçalo do Amarante $(2,2 \%)$ apresentaram crescimento bem próximo ao da Capital. Maracanaú $(1,5 \%)$ e Guaiúba $(1,4 \%)$ tiveram taxas menores em relação a Fortaleza. O único caso de decréscimo nessa década foi Pacatuba, com -1,7, devido ao seu desmembramento que deu origem a cidade de Itaitinga.

Tabela 2 - Taxa média geométrica de crescimento anual da população (\%) - RMF 1980-2010

\begin{tabular}{lcccc}
\hline \multicolumn{1}{c}{ Município } & Taxa 1980-1991 & Taxa 1991-2000 & Taxa 2000-2010 \\
\hline Fortaleza & 2,78 & 2,1 & 1,3 \\
\hline Caucaia & 5,24 & 4,7 & 2,6 \\
\hline Maracanaú & - & 1,5 & 1,6 \\
\hline Maranguape & $-2,16$ & 2,3 & 2,5 \\
\hline Aquiraz & 0,24 & 3,0 & 1,9 \\
\hline Pacatuba & 3,30 & $-1,7$ & 3,4 \\
\hline Cascavel & - & 2,3 & 1,5 \\
\hline Pacajus & $-3,49$ & 3,7 & 3,4 \\
\hline Horizonte & - & 7,1 & 5,0 \\
\hline Eusébio & - & 4,9 & 3,9 \\
\hline São Gonçalo & 1,56 & 2,2 & 2,1 \\
\hline Itaitinga & - & - & 2,1 \\
\hline Guaiuba & - & 1,4 & 1,9 \\
\hline Chorozinho & - & 2,1 & 0,1 \\
\hline Pindoretama & - & 2,1 & 2,3 \\
\hline Total & $\mathbf{3 , 4 6}$ & $\mathbf{2 , 4}$ & $\mathbf{1 , 6 8}$ \\
\hline
\end{tabular}

Fonte: Elaboração própria a partir dos microdados dos Censos Demográficos de 1980, 1991, 2000 e 2010 IBGE. 
De 2000 a 2010, a RMF teve crescimento de somente 1,68\%. Os municípios que apresentaram os níveis de crescimento mais elevados foram Horizonte (5\%), Eusébio (3,9\%), Pacatuba e Pacajus (ambos com 3,4\%). Nesta década, o município que apresentou níveis mais baixos foi Chorozinho $(0,1 \%)$. Fortaleza $(1,3 \%$ a.a.) teve a menor taxa das décadas apresentadas, assim como a RMF, com somente $1,7 \%$ (Tabela 2).

\subsubsection{Vetores de Expansão Urbano e Metropolitano da RMF}

Segundo Bernal (2003), citada por Gonçalves (2011), a expansão e integração da RM de Fortaleza tem se dado ao longo de quatro vetores de crescimento. Atualmente, os principais canais de ligação entre os municípios que constituem a RMF são as rodovias estaduais ou federais que conectam Fortaleza às cidades do interior ou a outros estados que auxiliam a identificação dos quatro eixos de expansão urbano-metropolitana (NOGUEIRA, 2011) (Figura 2).

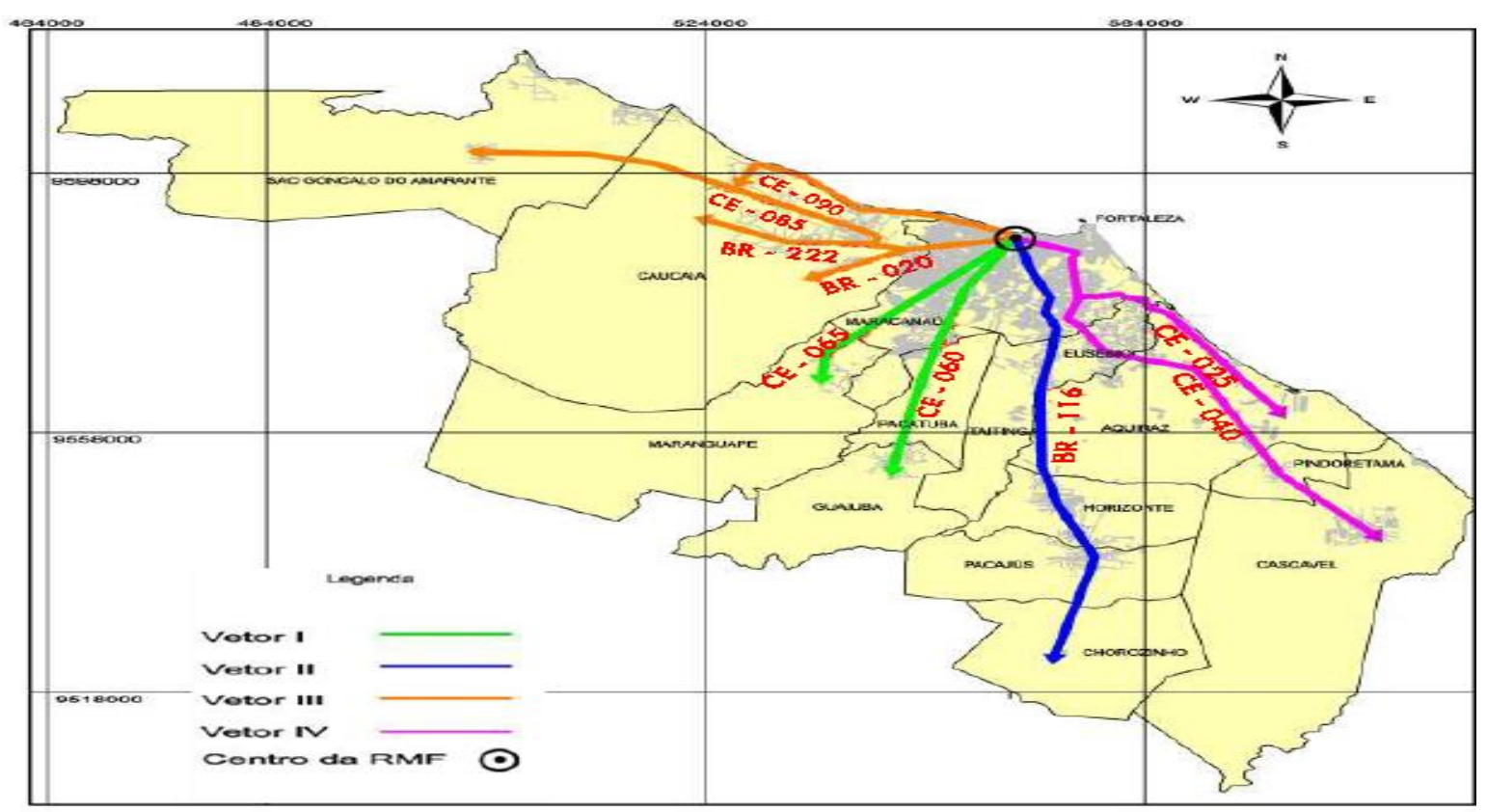

Figura 2 - Vetores de expansão da RMF

Fonte: Nogueira (2011, p. 43).

O primeiro vetor está situado no Distrito Industrial de Maracanaú, que foi inserido entre as décadas de 1960-1970 de acordo com as regras de planejamento econômico criados pela Superintendência do Desenvolvimento do Nordeste (SUDENE) e pelo Governo estadual. Os setores mais privilegiados nesta etapa de investimentos industriais realizados no Ceará foram o têxtil, confecções, alimentos e metal mecânico introduzidas no município de Maracanaú (DIÓGENES, 2012). 
Com a política de atendimento a déficits habitacionais do Banco Nacional de Habitação (BNH) e a existência do eixo ferroviário Sul ao redor desse distrito industrial (Maracanaú), começaram a surgir conjuntos habitacionais, na década de 1970-1980, que visavam desafogar o núcleo da RMF (DIÓGENES, 2012).

O segundo vetor que está localizado ao Sudeste da capital cearense, seguindo na direção da BR-116, é composto pelos municípios de Eusébio, Horizonte e Pacajus (Nogueira, 2011). A BR-116 é uma das mais importantes rodovias que conectam o Nordeste e o Sul do Brasil. Ela se inicia na capital cearense (e alcança o município de Jaguarão no Rio Grande do Sul), e passa pelas cidades de Eusébio, Itaitinga, Horizonte, Pacajus e Chorozinho, que fazem parte da RMF (DIÓGENES, 2012).

Este eixo caracteriza-se pela industrialização implantada no cenário das políticas estaduais de incentivos fiscais do final da década de 1980 nos municípios de Eusébio, Horizonte e Pacajus (Paiva, 2010). Além de incentivos fiscais e financeiros, o governo estadual financiou disponibilidades de infraestrutura (abastecimento de água, energia e sistemas de comunicação) para as indústrias inseridas nesses municípios (NOGUEIRA, 2011).

O terceiro vetor se localiza na BR-222, que liga Fortaleza à Caucaia, e está relacionado aos fluxos pendulares casa, trabalho e escola, partindo dos conjuntos habitacionais do município de Caucaia (Bernal, 2003, apud Gonçalves, 2011). Conforme Nogueira (2011, p. 40): “em Caucaia, a oferta de transportes em diversas modalidades (ônibus, trem e vans) fortalece os vínculos com a cidade polo. Os dados sobre o movimento pendular (2000) revelaram que $19 \%$ da população residente no município trabalha ou estuda em Fortaleza." Mais recentemente, de acordo com Nogueira (2011), a ação industrialportuária estabelecida em Caucaia e em São Gonçalo do Amarante (BR-020, CE-085 e CE090) também tem caracterizado este eixo (Figura 2).

A incorporação do Complexo Industrial e Portuário do Pecém (CIPP) inserido entre os municípios de São Gonçalo do Amarante e Caucaia, a aproximadamente $60 \mathrm{~km}$ de Fortaleza, é a mais atual etapa de ocupação desse vetor e deve aumentar cada vez mais a concentração de pessoas em busca de emprego, acentuando a expansão urbana nesse território e ampliando o espaço metropolitano. Sua inauguração foi feita em março de 2002 e é considerado um dos maiores investimentos feitos na Região Metropolitana de Fortaleza, projetado pelo Governo Estadual, como um artifício para impulsionar diversos setores da economia cearense (DIÓGENES, 2012). 
O Porto do Pecém faz parte do CIPP (Complexo Industrial e Portuário do Pecém) e é administrado pela empresa do Governo Estadual chamada Ceará Portos. Foi criado no intuito de proporcionar operações portuárias mais competitivas e eficazes, com fáceis acessos ferroviários e rodoviários, tão como auxiliar o fluxo do Complexo Industrial do Pecém. O porto compreende uma área de $75.000 \mathrm{~km}^{2}$, suas principais cargas embarcadas são frutas, calçados, pescados, couros e produtos têxteis e as cargas que mais desembarcam são insumos siderúrgicos, granéis líquidos e gás natural, e é composto por uma equipe de cerca de 750 funcionários, divididos entre trabalhadores do Ceará Portos e de empresas terceirizadas (DIÓGENES, 2012).

O quarto e último vetor envolve os municípios de Eusébio e Aquiraz, e é caracterizado pela urbanização litorânea agregada ao veraneio marítimo, ao turismo litorâneo e, atualmente à transformação dessas áreas em espaços de primeira residência. Esse eixo acompanha o direcionamento de duas rodovias principais: a CE-040, acompanhando a direção leste, e a CE025, acompanhando na direção Sudeste (DANTAS, 2009).

Os fatores que estimularam o setor imobiliário nesse vetor foram a disponibilidade de terrenos e a proximidade com bairros valorizados em Fortaleza, vinculado a presença de uma ampla faixa de praia em Aquiraz (NOGUEIRA, 2011).

Esse vetor de expansão metropolitana se desenvolve de maneira diferente dos demais. Primeiramente pela rapidez com que vem transformando o espaço urbano, já que há pouco tempo grande parte desse território era despovoado. Também é o vetor que apresenta tendência à dispersão urbana mais intensa, pela existência de condomínios horizontais e núcleos direcionados para o turismo e lazer (DIÓGENES, 2012).

\section{FLUXOS MIGRATÓRIOS INTRAMETROPOLITANOS: O CASO DA REGIÃO METROPOLITANA DE FORTALEZA - 1986/1991, 1995/2000 e 2005/2010}

\subsection{PROCEDIMENTOS METODOLÓGICOS}

Os microdados dos Censos Demográficos de 1991, 2000 e 2010 são a principal fonte de informação. Por sua vez, os conceitos adotados no estudo são os seguintes:

Migrante intrametropolitano de data fixa - indivíduo (natural ou não natural) da RMF, com cinco anos ou mais de idade, que na data de referência do Censo Demográfico residia num município da RMF, mas em uma data fixa (exatamente cinco anos antes do recenseamento) morava em outro município da RMF.

Saldo migratório - representa a diferença entre o total de imigrantes e de emigrantes de data fixa. 
Núcleo - município de Fortaleza.

Periferia - municípios da RMF, exclusive Fortaleza.

Núcleo-periferia - migração do núcleo (Fortaleza) em direção aos municípios da periferia.

Periferia-núcleo - migração dos municípios da periferia em direção ao núcleo (Fortaleza).

Periferia-periferia - migração entre os municípios da periferia da RMF.

Quanto a matriz migratória, esta foi construída para os quinze municípios que formam a RMF. Assim, a matriz intrametropolitana da RMF apresenta-se da seguinte forma:

$$
\begin{aligned}
& {\left[\begin{array}{ccc}
a 11 & \cdots & a 1 j \\
\vdots & \ddots & \vdots \\
a j 1 & \cdots & a j j
\end{array}\right]} \\
& \mathrm{A}= \\
& \mathrm{a}_{\mathrm{ij}}=\text { saída do migrante do município i para o município } \mathrm{j} \\
& \sum_{j=1}^{15} a 1 j \quad=\text { total de pessoas que emigram (saída) do município } 1 \text { para os demais } \\
& \sum_{i=1}^{15} a i 1 \quad \quad \text { municípios da RMF } \\
& \mathrm{a}_{11}=\mathrm{a}_{22}=\mathrm{a}_{33}=\ldots=\mathrm{a}_{\mathrm{jj}}=0
\end{aligned}
$$

A partir desta matriz é possível identificar os fluxos migratórios intrametropolitanos (entre os quinze municípios da RMF) e identificar os municípios que mais recebem imigrantes, os que mais perdem emigrantes bem como o saldo migratório de cada município.

\subsection{EVOLUÇÃO DO FLUXO MIGRATÓRIO NA RMF}

A Tabela 3 mostra o fluxo migratório intrametropolitano na Região Metropolitana de Fortaleza, tendo como categoria de análise o migrante de data fixa, durante os quinquênios de 1986/1991, 1995/2000 e 2005/2010 . É possível observar que o fluxo intrametropolitano apresentou descenso nos intervalos em estudo, ao passar de 75.601 migrantes envolvidos

\footnotetext{
${ }^{1}$ Maiores detalhes sobre o conceito de migrante adotado nesse estudo veja a seção metodológica.
} 
nesse processo entre 1986/1991, para 73.950 no período $1995 / 2000$, arrefecendo para 67.964 pessoas no quinquênio 2005/2010.

Tabela 3 - Migrantes intrametropolitanos - RMF - 1986/1991, 1995/2000 e 2005/2010 (Data fixa).

\begin{tabular}{l|c|c|c|c|rr}
\hline \multirow{2}{*}{$\begin{array}{c}\text { Migrantes } \\
\text { Intrametropolitanos }\end{array}$} & \multicolumn{2}{|c|}{$\mathbf{1 9 8 6 / 1 9 9 1}$} & \multicolumn{2}{c|}{$\mathbf{1 9 9 5 / 2 0 0 0}$} & \multicolumn{2}{c}{$\mathbf{2 0 0 5 / 2 0 1 0}$} \\
\cline { 2 - 8 } Migrantes de data fixa & Abs. & $\mathbf{( \% )}$ & Abs. & $(\boldsymbol{\%})$ & \multicolumn{1}{c}{ Abs. } & $(\boldsymbol{\%})$ \\
\hline Núcleo-periferia & $\mathbf{7 5 . 6 0 1}$ & $\mathbf{1 0 0 , 0 0}$ & $\mathbf{7 3 . 9 5 0}$ & $\mathbf{1 0 0 , 0 0}$ & $\mathbf{6 7 . 9 6 4}$ & $\mathbf{1 0 0 , 0 0}$ \\
\hline Periferia-núcleo & 53.126 & 70,27 & 50.920 & 68,86 & 44.091 & 64,87 \\
\hline Periferia-periferia & 10.542 & 13,94 & 9.732 & 13,16 & 9.282 & 13,66 \\
\hline
\end{tabular}

Fonte: Elaboração própria a partir dos microdados dos Censos Demográficos de 1991, 2000 e 2010 - IBGE

Quanto ao fluxo de migrantes do núcleo (Fortaleza) em direção à periferia (demais municípios da RMF), o número de pessoas diminui ao longo dos anos, tanto em termos absolutos quanto relativos. O contingente humano passou de $53.126(70,27 \%)$ migrantes entre 1986/1991, para 44.091 (64,87\%) no período 2005/2010. Tal dinâmica apresenta semelhança com aqueles que partiram da periferia em direção ao núcleo da RMF (Fortaleza), ao apresentar descenso em termos absolutos, mas em termos relativos não sofreu mudanças significativas. No intervalo de 1986/1991, 13,94\% dos migrantes da RMF fizeram o movimento periferia-núcleo, parcela essa que cai para 13,16\% em 1995/2000, com pequeno acréscimo (13,66\%) em 2005/2010 (Gráfico 1).

\section{Gráfico 1 - Fluxo migratório em termos relativos na RMF - 1986/1991, 1995/2000 e 2005/2010 (Data fixa)}

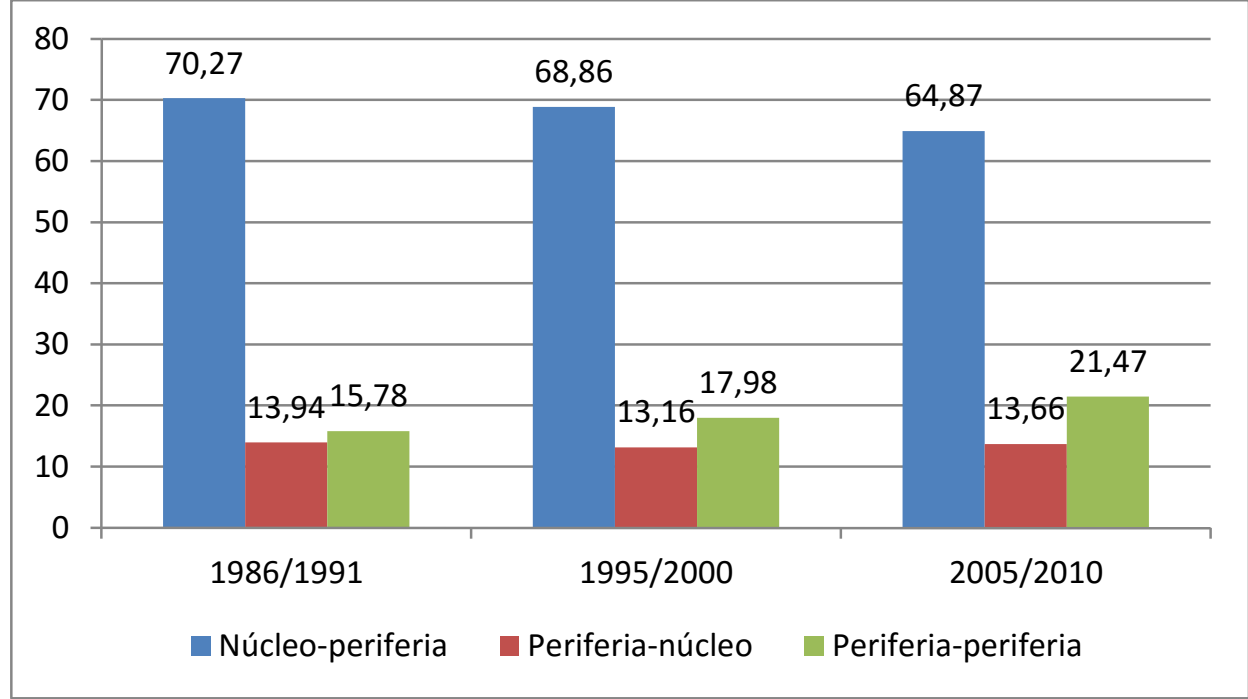

Fonte: Elaboração própria a partir dos microdados dos Censos Demográficos de 1991, 2000 e 2010 - IBGE 
Por sua vez, o fluxo que exibe contínuo crescimento, seja em números absolutos ou relativos, é o movimento periferia-periferia. Em 1986/1991, representava 15,78\% dos migrantes de data fixa da RMF (11.933 migrantes de um total de 75.601), porcentagem que chegou a 21,47\% no último quinquênio estudado (14.591 migrantes de um total de 67.964) (Tabela 3, Gráfico 1). Tal movimento indica o crescimento dos municípios periféricos, dado que a população de Fortaleza (núcleo) ao longo dos três quinquênios em estudo, cada vez mais, migra para a periferia e, por sua vez, a população da periferia passa a se deslocar entre os próprios municípios, seja por questões econômicas (oportunidade de emprego), habitacionais, seja em busca de melhor qualidade de vida.

A próxima seção aborda de maneira minuciosa o volume de emigrantes, imigrantes e saldos migratórios dos quinze municípios que compõe a Região Metropolitana de Fortaleza, procurando apontar para as principais mudanças/inflexões ao longo do período em estudo.

\subsection{IMIGRANTES, EMIGRANTES E SALDO MIGRATÓRIO NOS MUNICÍPOS DA RMF}

No tocante ao fluxo migratório intrametropolitano, no período de 1986/1991, a RMF contou com um movimento de 75.601 migrantes. Dentre eles, chegaram ao núcleo (Fortaleza) 10.542 imigrantes $(13,94 \%)$ e saíram 53.126 pessoas $(70,27 \%)$, deixando o município com saldo migratório negativo de -42.484 indivíduos, se destacando como a área de maior perda populacional na RMF. Por sua vez, Maracanaú foi outro município de destaque, ao contar com uma entrada de 20.593 imigrantes (27,24\%) e saída de 1.866 (2,47\%) emigrantes, tornando o município com o maior saldo migratório positivo da RMF (18.727) neste quinquênio. Caucaia foi outro município atrativo, ao apresentar entrada de 21.044 imigrantes e saída de 3.927 emigrantes (5,19\%), rendendo-lhe saldo migratório de 17.117 indivíduos (Tabela 4).

Tabela 4 - Fluxos migratórios intrametropolitanos - RMF - 1986/1991 (Data fixa)

\begin{tabular}{l|r|r|r|r|r}
\hline Municípios & Imigrantes & \multicolumn{1}{c|}{$(\boldsymbol{\%})$} & \multicolumn{1}{c|}{ Emigrantes } & \multicolumn{1}{c|}{$(\boldsymbol{\%})$} & \multicolumn{1}{c}{ Saldo } \\
\hline Aquiraz & 2.993 & 3,96 & 1.710 & 2,26 & 1.283 \\
\hline Cascavel & 1.724 & 2,28 & 2.563 & 3,39 & -839 \\
\hline Caucaia & 21.044 & 27,84 & 3.927 & 5,19 & 17.117 \\
\hline Chorozinho & 749 & 0,99 & 925 & 1,22 & -176 \\
\hline Eusébio & 1.886 & 2,49 & 319 & 0,42 & 1.567 \\
\hline Fortaleza & 10.542 & 13,94 & 53.126 & 70,27 & -42.584 \\
\hline Guaiuba & 482 & 0,64 & 564 & 0,75 & -82 \\
\hline Horizonte & 1.127 & 1,49 & 677 & 0,90 & 450 \\
\hline Maracanaú & 20.593 & 27,24 & 1.866 & 2,47 & 18.727 \\
\hline Maranguape & 1.658 & 2,19 & 4.472 & 5,92 & -2.814 \\
\hline Pacajus & 1.746 & 2,31 & 1.663 & 2,20 & 83 \\
\hline
\end{tabular}




\begin{tabular}{l|r|r|r|r|r}
\hline Pacatuba & 9.056 & 11,98 & 1.642 & 2,17 & 7.414 \\
\hline Pindoretama & 642 & 0,85 & 675 & 0,89 & -33 \\
\hline S. G. do Amarante & 1.359 & 1,80 & 1.472 & 1,95 & -113 \\
\hline Total da RMF & $\mathbf{7 5 . 6 0 1}$ & $\mathbf{1 0 0 , 0 0}$ & $\mathbf{7 5 . 6 0 1}$ & $\mathbf{1 0 0 , 0 0}$ & - \\
\hline
\end{tabular}

Fonte: Elaboração própria a partir dos microdados dos Censos Demográficos de 1991, 2000 e 2010 - IBGE

A grande quantidade de emigrantes que saíram de Fortaleza deve-se em parte ao crescimento econômico dos municípios periféricos (BRITO, 2006), além do encarecimento do preço dos imóveis em tal área (Nogueira; Silva, 2010). Por sua vez, a atratividade de Maracanaú deve-se à implantação do polo industrial na cidade, entre as décadas de 19601970, e a construção de conjuntos habitacionais, entre as décadas de 1970-1980 (Diógenes, 2012). Nesse período, também é possível observar que Caucaia recebia migrantes, devido, em parte, à construção de conjuntos habitacionais em seu território (Gonçalves, 2011), mas é no quinquênio seguinte que a sua atratividade fica evidente, com o seu saldo migratório ultrapassando Maracanaú (Tabela 5).

Tabela 5 - Fluxos migratórios intrametropolitanos - RMF - 1995/2000 (Data fixa)

\begin{tabular}{l|r|r|r|r|r}
\hline Municípios & Imigrantes & $\mathbf{( \% )}$ & Emigrantes & \multicolumn{1}{c}{$(\mathbf{\%})$} & \multicolumn{1}{c}{ Saldo } \\
\hline Aquiraz & 3.749 & 5,07 & 1.832 & 2,48 & 1.917 \\
\hline Cascavel & 2.132 & 2,88 & 2.190 & 2,96 & -58 \\
\hline Caucaia & 21.914 & 29,63 & 3.313 & 4,48 & 18.601 \\
\hline Chorozinho & 599 & 0,81 & 1.539 & 2,08 & -940 \\
\hline Eusébio & 2.947 & 3,99 & 839 & 1,13 & 2.108 \\
\hline Fortaleza & 9.732 & 13,16 & 50.920 & 68,86 & -41.188 \\
\hline Guaiuba & 602 & 0,81 & 903 & 1,22 & -301 \\
\hline Horizonte & 4.255 & 5,75 & 617 & 0,83 & 3.638 \\
\hline Itaitinga & 1.560 & 2,11 & 562 & 0,76 & 998 \\
\hline Maracanaú & 14.133 & 19,11 & 4.725 & 6,39 & 9.408 \\
\hline Maranguape & 2.463 & 3,33 & 2.885 & 3,90 & -422 \\
\hline Pacajus & 2.649 & 3,58 & 1.240 & 1,68 & 1.409 \\
\hline Pacatuba & 5.158 & 6,97 & 1.134 & 1,53 & 4.024 \\
\hline Pindoretama & 836 & 1,13 & 476 & 0,64 & 360 \\
\hline S. G. do Amarante & 1.221 & 1,65 & 775 & 1,05 & 446 \\
\hline Total da RMF & $\mathbf{7 3 . 9 5 0}$ & $\mathbf{1 0 0 , 0 0}$ & $\mathbf{7 3 . 9 5 0}$ & $\mathbf{1 0 0 , 0 0}$ & - \\
\hline
\end{tabular}

Fonte: Elaboração própria a partir dos microdados dos Censos Demográficos de 1991, 2000 e 2010 - IBGE

No intervalo entre 1995/2000, o movimento migratório da RMF contou com o deslocamento de 73.950 pessoas, quantidade inferior ao período passado (75.601). O número de imigrantes em Fortaleza foi de 9.732 (13,16\%) e o de emigrantes de 50.920 (68,86\%), com saldo migratório negativo de -41.188 pessoas, persistindo como a maior área de perda populacional da RMF. Em Caucaia houve a entrada de 21.914 imigrantes $(29,63 \%)$ e a saída de 3.313 emigrantes $(4,48 \%)$, acarretando ao município o maior saldo migratório positivo da 
Região Metropolitana (18.601). Maracanaú, por sua vez, sofreu grande perda na quantidade de imigrantes, com entrada de 14.133 indivíduos (19,11\%) e emigração de 4.725 (6,39\%) pessoas, obtendo saldo migratório de 9.408 indivíduos, quase metade do saldo (18.727) em 1986/1991 (Tabelas 4 e 5).

O processo de crescimento urbano de Caucaia iniciou-se a partir da construção de conjuntos habitacionais no município, que em virtude da proximidade com o núcleo (Fortaleza) e os seus serviços, valorização do solo e fácil acesso ao mesmo (ferroviárias, rodoviárias e um sistema de transporte coletivo) (Gonçalves, 2011), atraiu quantidade expressiva de migrantes da RMF.

Quanto ao fluxo mais recente, a Tabela 6 mostra que a população da RMF tem se deslocado cada vez menos. Entre 1986/1991, 75.601 pessoas migraram entre os quinze municípios da RMF (Tabela 4), número que caiu para 67.964 em 2005/2010 (Tabela 6). Fortaleza, assim como nos quinquênios anteriores, continua com o maior saldo migratório negativo (-34.809). Já Caucaia, permaneceu como o município com o maior saldo migratório positivo (13.477), seguido de Maracanaú (5.832).

Tabela 6 - Fluxos migratórios intrametropolitanos - RMF - 2005/2010 (Data fixa)

\begin{tabular}{l|r|r|r|r|r}
\hline Municípios & Imigrantes & \multicolumn{1}{c|}{$(\mathbf{\%})$} & Emigrantes & \multicolumn{1}{c}{$(\boldsymbol{\%})$} & \multicolumn{1}{c}{ Saldo } \\
\hline Aquiraz & 4.607 & 6,78 & 1.975 & 2,91 & 2.632 \\
\hline Cascavel & 2.597 & 3,82 & 1.551 & 2,28 & 1.046 \\
\hline Caucaia & 17.405 & 25,61 & 3.928 & 5,78 & 13.477 \\
\hline Chorozinho & 556 & 0,82 & 1.330 & 1,96 & -774 \\
\hline Eusébio & 4.701 & 6,92 & 944 & 1,39 & 3.757 \\
\hline Fortaleza & 9.282 & 13,66 & 44.091 & 64,87 & -34.809 \\
\hline Guaiuba & 458 & 0,67 & 740 & 1,09 & -282 \\
\hline Horizonte & 4.697 & 6,91 & 1.396 & 2,05 & 3.301 \\
\hline Itaitinga & 1.862 & 2,74 & 1.002 & 1,47 & 860 \\
\hline Maracanaú & 9.942 & 14,63 & 4.110 & 6,05 & 5.832 \\
\hline Maranguape & 1.860 & 2,74 & 2.354 & 3,46 & -494 \\
\hline Pacajus & 3.517 & 5,17 & 2.088 & 3,07 & 1.429 \\
\hline Pacatuba & 2.455 & 3,61 & 1.130 & 1,66 & 1.325 \\
\hline Pindoretama & 1.299 & 1,91 & 603 & 0,89 & 696 \\
\hline S. G. do Amarante & 2.726 & 4,01 & 722 & 1,06 & 2.004 \\
\hline Total da RMF & $\mathbf{6 7 . 9 6 4}$ & $\mathbf{1 0 0 , 0 0}$ & $\mathbf{6 7 . 9 6 4}$ & $\mathbf{1 0 0 , 0 0}$ & \\
\hline
\end{tabular}

Fonte: Elaboração própria a partir dos microdados dos Censos Demográficos de 1991, 2000 e 2010 - IBGE.

É pertinente observar o município de São Gonçalo do Amarante, no quinquênio de 1986/1991, o mesmo apresentou saldo migratório negativo de -113 indivíduos, e no quinquênio seguinte foi positivo em 446 pessoas, aumentando para 2.044 indivíduos entre 2005/2010 (Tabelas 4, 5 e 6). 
O crescimento populacional de Caucaia e de São Gonçalo do Amarante em anos recentes deve-se à incorporação do Complexo Industrial e Portuário do Pecém, inaugurado em 2002. A obra está atraindo população em busca de empregos, intensificando a expansão urbana nos dois municípios.

Em resumo, esta seção revelou que o movimento migratório na RMF, ao longo dos três quinquênios em estudo, paulatinamente apresenta diminuição no seu volume. Ademais, em nível municipal, Fortaleza segue tal tendência, ao perder população para os municípios da periferia, enquanto Caucaia e Maracanaú, localizados respectivamente nos vetores 3 e 1 (Figura 2), destacam-se por sua atratividade populacional, em razão do crescimento econômico, conjuntos habitacionais e infraestutura. Além disso, apesar de menos volumoso, destaca-se o intenso aumento no saldo migratório de São Gonçalo do Amarante, possivelmente associado à instalação do Porto do Pecém.

\subsection{ORIGEM E DESTINO DOS MIGRANTES INTRAMETROPOLITANOS NA RMF}

As matrizes migratórias a seguir (Matriz 1, Matriz 2 e Matriz 3$)^{2}$ mostram a origem e o destino dos migrantes de data fixa entre os municípios da Região Metropolitana de Fortaleza, nos quinquênios de 1986/1991, 1995/2000 e 2005/2010.

A Matriz 1, em anexo, destaca que, entre 1986/1991, Fortaleza recebeu 10.542 pessoas, sendo a grande maioria do município de Maranguape (2.264), Caucaia (2.185), Cascavel (1.279) e São Gonçalo do Amarante (1.070). No tocante as saídas, o núcleo (Fortaleza) detém o maior número de emigrantes (53.126), sendo os principais destinos Caucaia (19.708) e Maracanaú (17.919), apresentando saldo migratório negativo (-42.584).

Por sua vez, Caucaia foi o município da RMF que recebeu o maior volume de imigrantes de data fixa (21.044 indivíduos), tendo como origem principal a cidade de Fortaleza (19.708) que também foi o destino mais procurado por aqueles que saíram de Caucaia (2.185), ficando com saldo migratório de 17.177 pessoas. Com relação a Maracanaú, um dos principais municípios de maior atração da RMF, dos 20.593 imigrantes que chegaram, 17.919 veio de Fortaleza, e dos 1.866 emigrantes que deixaram o município, 642 tiveram Pacatuba como destino principal, totalizando saldo migratório de 18.727 migrantes (Matriz 1).

Sendo assim, entre 1986/1991, o movimento migratório da Região Metropolitana de Fortaleza concentra-se notadamente nos municípios de Fortaleza, Caucaia e Maracanaú.

\footnotetext{
${ }^{2}$ As matrizes migratórias encontram-se em anexo.
} 
Como mencionado na seção anterior, Fortaleza perdeu grande parte da sua população devido o encarecimento do preço dos imóveis (NOGUEIRA; SILVA, 2010) (BRITO, 2006).

Por sua vez, Caucaia atraiu grande contingente populacional em consequência da construção de conjuntos habitacionais em seu território. O desenvolvimento e a ampliação residencial de Fortaleza em direção a parte oeste do município estimularam crescimento residencial em Caucaia. Essa expansão da metrópole na direção da periferia engloba parte de Caucaia que contém amplas áreas habitadas por população, sobretudo, as de renda mais baixa (TELES, 2005).

Já Macanaú se beneficiou com a construção do primeiro polo industrial do Ceará em 1966 e de seis grandes conjuntos habitacionais a partir da década de 1980 (CARVALHO, 2009), sendo, por esses motivos, um dos possíveis motivos da sua expressiva atratividade de imigrantes entre os municípios da RMF.

Quanto ao intervalo entre 1995/2000, representado pela Matriz 2, Fortaleza recebeu 9.732 imigrantes, quantidade inferior ao período passado (10.542), sendo a maioria vinda dos municípios de Maracanaú (2.051), Caucaia (1.694), Maranguape (1.343) e Cascavel (1.069). Em relação às saídas, Fortaleza continua com o maior número de emigrantes da RMF (50.920), tendo como principais destinos Caucaia (20.405) e Maracanaú (11.839), totalizando saldo migratório negativo de -41.188 pessoas - o maior da RMF.

No entanto, conforme constatado no quinquênio anterior, Caucaia foi o município da RMF que recebeu a maior quantidade de imigrantes (21.914), desses, 20.405 originaram-se de Fortaleza. Em relação às saídas, Caucaia teve 3.313 emigrantes, sendo que 1.694 tiveram como destino o núcleo da RMF (Fortaleza), totalizando saldo migratório de 18.601 (Matriz 2).

Já Maracanaú, apresentou queda na atratividade, ao passar de 20.593 para 14.133, entre 1986/1991 e 1995/2000, respectivamente, com a grande maioria (11.839) procedente de Fortaleza. Quanto à emigração, houve a saída de 4.725 pessoas, que tiveram como principais destinos Fortaleza (2.051) e Pacatuba (1.070). Com isso, o saldo migratório de Maracanaú foi de 9.408 cidadãos nesse quinquênio, contra 18.727 no período anterior (Matriz 2).

Dessa forma, entre 1995/2000, Fortaleza, Caucaia e Maracanaú continuam como os municípios de maior concentração migratória da Região Metropolitana de Fortaleza. Ademais, chama atenção para a quantidade de emigrantes que saíram de Maracanaú em direção à Pacatuba, que passou de 642 pessoas para 1.070, entre os dois primeiros quinquênios analisados. Nesse contexto, o crescimento do movimento migratório para Pacatuba possivelmente se deve ao fato de que: 
A partir da década de 1990, com o chamado "Governo das Mudanças", o perfil econômico de Pacatuba começa a mudar e o município passa a ganhar destaque no cenário metropolitano com as dinâmicas engendradas em seu território, em especial a industrialização. [...] A presença dessas empresas é fruto de uma investida por parte do município e do governo do Estado em desenvolver mecanismos para atração e consolidação de investimentos industriais, sendo os incentivos fiscais, o apoio financeiro e a implantação de uma infra-estrutura básica de funcionamento os principais atrativos oferecidos às empresas (CARDOSO, 2010, p.8)

Quanto a Matriz 3, que representa o fluxo migratório na RMF entre 2005/2010, constata-se que Fortaleza recebeu 9.282 imigrantes, a maioria originados de Caucaia (2.134), Maracanaú (1.810) e Maranguape (916). Por sua vez, o volume de emigrantes foi de 44.091 pessoas, com a maior parte indo para Caucaia (15.874), Maracanaú (7.805), Eusébio (4.045) e Aquiraz (3.158). Assim, Fortaleza permaneceu como o município de maior saldo migratório negativo (-34.809), contudo, menor quando comparado ao quinquênio anterior (-41.188).

Com relação a Caucaia, este município continua recebendo a maior quantidade de imigrantes (17.405), dentre eles, 15.874 procedentes de Fortaleza. No que diz respeito à emigração, foram 3.928 saídas, no qual 2.134 tiveram como direção o núcleo da RMF (Fortaleza). Dessa forma, Caucaia exibe saldo migratório de 13.477 pessoas, que apesar de ter apresentado grande perda em relação ao período de 1995/2000 (18.601), o município manteve-se como o maior saldo positivo da Região Metropolitana (Matriz 3).

No tocante a Maracanaú, o contigente de imigrantes foi de 9.942 pessoas, sendo 7.805 oriundos do núcleo da RMF. Por sua vez, partiram do município 4.110 pessoas, principalmente para Fortaleza (1.810) e Pacatuba (867). Logo, Maracanaú teve saldo migratório de 5.832 cidadãos, quantidade inferior ao período passado (9.408) (Matriz 3).

Com isso, Fortaleza, Caucaia e Maracanaú foram em 2005/2010, como nos quinquênios anteriores, os principais municípios de entrada e saída de população da Região Metropolitana de Fortaleza. Contudo, vale ressaltar que os municípios de Eusébio e Aquiraz receberam boa parte dos emigrantes de Fortaleza nesse período. Isso se deve ao desenvolvimento acelerado dos dois municípios: em Eusébio, de acordo com Nogueira (2011, p.35): “caracterizou-se pelo crescimento das atividades imobiliárias em seu território e pelo incremento no número de indústrias nos últimos anos”. Em Aquiraz, está vinculado à urbanização litorânea, turismo e funções habitacionais atrativas principalmente para pessoas de classe média (PEREIRA, 2009).

Portanto, essa seção deixa evidente que o movimento migratório na RMF, nos três quinquênios analisados, concentra-se principalmente nos municípios de Fortaleza, Caucaia e Maracanaú. Sendo que Fortaleza seguiu sempre uma tendência de perda populacional para a periferia. Por sua vez, Caucaia e Maracanaú apresentaram-se como os municípios de maior 
atratividade na migração intrametropolitana, sempre recebendo as maiores quantidades de emigrantes do núcleo. Segundo Nogueira (2011, p. 36): “o crescimento desses municípios tem ocorrido, sobretudo, em virtude do deslocamento da população na RMF no sentido poloperiferia." Dessa maneira, os municípios periféricos seguem expressando saldos migratórios mais elevados quando comparado a Fortaleza.

\section{CONCLUSÕES}

As primeiras metrópoles brasileiras foram criadas em 1973, dentre elas estava a Região Metropolitana de Fortaleza. Inicialmente composta por cinco municípios, número que triplicou desde a sua institucionalização, atingindo um total de quinze cidades em 2010.

Espacialmente esses municípios estão divididos em quatro vetores de expansão: o primeiro engloba os municípios de Maracanaú, Pacatuba, Horizonte e Guaiuba, e está ligado à instalação do complexo industrial de Maracanaú, que estimulou o surgimento de conjuntos habitacionais; o segundo vetor envolve Eusébio, Horizonte e Pacajus, e está relacionado á industrialização implantada pelas políticas estaduais de incentivos fiscais; o terceiro é composto por Caucaia e São Gonçalo do Amarante, inicialmente relacionado aos fluxos pendulares de Caucaia para Fortaleza e depois à implementação do Complexo Industrial e Portuário do Pecém (CIPP); o quarto vetor se caracteriza pela urbanização litorânea nos municípios de Eusébio e Aquiraz.

Com relação à dinâmica econômica da RMF, em 2010, dentre os quinze maiores PIB's do Ceará, oito se encontravam na RMF, mostrando a concentração da atividade econômica em tal área. Devido a esse desenvolvimento econômico, há um grande fluxo migratório entre os municípios que compõe a RMF. Contudo, entre os três quinquênios em estudo, a migração intrametropolitana apresentou decréscimo, dado que a RMF atraiu 75.601 migrantes intrametropolitanos, no período de 1986/1991, diminuindo para 67.964, no último intervalo $(2005 / 2010)$.

Quanto à direção do fluxo, as migrações intrametropolitanas tiveram como principal sentido o movimento núcleo-periferia, apontando para a perda populacional do núcleo (Fortaleza) para os municípios da periferia (demais municípios da RMF). Com isso, o movimento periferia-periferia aumentou ao longo dos quinquênios em estudo, seja por oportunidades de emprego ou por questões habitacionais.

No tocante aos municípios que compõe a RMF, Fortaleza (núcleo da RMF) apresentou saldo migratório negativo nos três interregnos em estudo, tipificando como área de maior 
perda populacional. Tal tendência se deve a diversos fatores, dentre eles, o crescimento econômico dos municípios periféricos e o encarecimento do preço dos imóveis na RMF.

Por sua vez, os municípios que se mostraram mais atrativos foram Caucaia e Maracanaú. Caucaia, devido à construção de conjuntos habitacionais em seu território, proximidade e fácil acesso com Fortaleza. Em termos migratórios foi o município com maior atratividade populacional durante os três quinquênios, atingindo saldo migratório positivo de 13.477 pessoas, entre 2005/2010. Por sua vez, Maracanaú obteve saldo migratório de 5.832 indivíduos no último período, atração que se deve à instalação de um polo industrial e a construção de conjuntos habitacionais no município.

Em síntese, ao longo dos períodos em análise foi constatada a nova tendência das migrações intrametropolitanas na RMF, a partir da saída de pessoas do núcleo (Fortaleza) em direção à periferia e o aumento na intensidade no volume migratório entre os municípios da periferia (o fluxo periferia-periferia). A partir de tal tendência, faz-se necessário pensar nas políticas públicas, no planejamento urbano e na elaboração/revisão do plano diretor dos municípios para os quais a população intrametropolitana da RMF está se dirigindo.

\section{REFERÊNCIAS BIBLIOGRÁFICAS}

BRITO F.. O deslocamento da população brasileira para as metrópoles. Instituto de Estudos Avançados da Universidade de São Paulo, São Paulo, v.20, n.57, p.221-236, 2006. Disponível em: <http://www.scielo.br/scielo.php?pid=S0103-40142006000200017\&script=sci_arttext>. Acesso em: 2 maio 2014.

CARDOSO, E. I. Metropolização e mobilidade intrametropolitana: o caso dos moradores de Pacatuba - CE. In: XVI ENCONTRO NACIONAL DOS GEÓGRAFOS, 6, p. 1-10, jul. 2010, Porto Alegre. Anais... 2010. Disponível em: <www.agb.org.br/evento/download.php?idTrabalho=794>. Acesso em: 18 março 2014.

CARVALHO, K. B. de. Territórios produtivos: estudo geográfico do I Distrito Industrial do Ceará. Fortaleza: UECE, 2009. 197 p. Disponível em:

<http://www.uece.br/mag/dmdocuments/keane_barroso_dissertacao.pdf.> Acesso em: 23 de fevereiro de 2015.

CEARÁ (Estado). Lei Complementar n 18, de 29 de dezembro de 1999. Dispõe sobre a Região Metropolitana de Fortaleza. Disponível em: <http://www.normasbrasil.com.br/norma/lei-complementar-18-1999ce_121501.html>. Acesso em: 3 de fevereiro de 2014.

DANTAS, E. W. C.. De Fortaleza à região metropolitana. In: Vulnerabilidade socioambiental na Região Metropolitana de Fortaleza. Fortaleza: Edições UFC, 2009. Disponível em:

<http://www.posgeografia.ufc.br/index.php?option=com_content\&view=article\&id=191:vulnerabilidadesocioambiental-na-regiao-metropolitana-de-fortaleza\&catid=70:livros-publicados\&Itemid=81>. Acesso em: 3 de maio de 2014.

DIOGENES, B. H. B. N. Dinâmicas urbanas recentes da área metropolitana de Fortaleza. 2012. Tese (Doutorado em História e Fundamentos da Arquitetura e do Urbanismo) - Faculdade de Arquitetura e Urbanismo, Universidade de São Paulo, São Paulo, 2012. Disponível em: 
<http://www.teses.usp.br/teses/disponiveis/16/16133/tde-03122012-131144/pt-br.php>. Acesso em: 02 de junho de 2014.

GONÇALVES, T. E.. Região Metropolitana de Fortaleza: o município de Caucaia na dinâmica de integração e mobilidade intrametropolitana. Revista Caminhos de Geografia, Uberlândia, v.12, n.40, p.144-154, dez. 2011. Disponível em: <http://www.seer.ufu.br/index.php/caminhosdegeografia/article/view/16554>. Acesso em: $11 \mathrm{de}$ fevereiro de 2014.

IBGE. Anuário Estatístico do Brasil de 1940, 1950 e 1960.

IBGE. Microdados dos Censos Demográficos de 1970, 1980, 1991, 2000, 2010.

IPECE. Anuário estatístico do Ceará 2012. Disponível em:

<http://www2.ipece.ce.gov.br/publicacoes/anuario/anuario2012/index.htm>. Acesso em: 18 de junho de 2014.

NOGUEIRA, C. M. L.. Expansão metropolitana contemporânea: a Região Metropolitana de Fortaleza no início do séc. XXI. In: XIII SIMPÓSIO NACIONAL DE GEOGRAFIA URBANA, 2013, Rio de Janeiro. Anais... 2013. Disponível em: <http://www.simpurb2013.com.br/wp-content/uploads/2013/11/cleiton.pdf>. Acesso em: 3 de fevereiro de 2014.

NOGUEIRA, C. M. L. Expansão metropolitana e dinâmica imobiliária: o município de Eusébio no contexto da Região Metropolitana de Fortaleza (RFM). 2011. 153 f. Dissertação (Mestrado) - Programa de Pós Graduação em Geografia, Universidade Federal do Ceará, Fortaleza, 2011. Disponível em: <http://www.repositorio.ufc.br/bitstream/riufc/7775/1/2011_dis_cmlnogueira.pdf>. Acesso em: 2 jul. 2014.

NOGUEIRA, C. M. L.; SILVA, J. B. da. Expansão Metropolitana e Mobilidade: o município contexto da Região Metropolitana de Fortaleza. In: XVI ENCONTRO NACIONAL DOS GEÓGRAFOS, 6., 2010, Porto Alegre. Anais... Porto Alegre: AGB, 2010. p. 1 - 10 . Disponível em: <www.agb.org.br/evento/download.php?idTrabalho=2524>. Acesso em: 27 jan. 2015.

PEREIRA, A. Q.. Estruturação urbana litorânea da Região Metropolitana de Fortaleza: planos para Aquiraz, Caucaia e São Gonçalo do Amarante. Mercator: Revista de Geografia da UFC, Fortaleza, n.15, p.49-57, 2009. Disponível em: 〈http://www.mercator.ufc.br/index.php/mercator/article/viewFile/215/215>. Acesso em: 24 mar. 2015.

PINHO, B. A. T. D. de.; BRITO, F.. Fluxos migratórios intrametropolitanos: o caso da região metropolitana de Belo Horizonte, 1970-2010. Belo Horizonte: UFMG/CEDEPLAR, 2013. 23 p. Texto para discussão. Disponível em: <http://www.cedeplar.ufmg.br/pesquisas/td/TD 472.pdf>. Acesso em: 30 jan. 2014.

TELES, G. A.. Dinâmicas metropolitanas contemporâneas: Caucaia na região metropolitana de fortaleza. 2005. 176 f. Dissertação (Mestrado) - Curso de Mestrado em Geografia, Centro de Ciências e Tecnologia, Universidade Estadual do Ceará, Fortaleza, 2005. Disponível em: <http://www.uece.br/mag/dmdocuments/glauciana_teles_dissertacao.pdf>. Acesso em: 2 fev. 2015.

TSUKUMO, I. T. L.; COSTA, M. A.; BOSCARIOL, R. A.; DANTAS, R. F.; SOARES, R. B.. Cap. Região Metropolitana de Fortaleza: desafios para governança num contexto de instabilidade dos arranjos de gestão. In: 40 anos de regiões metropolitanas no Brasil. IPEA (org.). v.1, 2013. Disponível em:

<http://www.ipea.gov.br/portal/images/stories/PDFs/temasrelevantes/livro_40_anos_de_regioes_metropolitanas _v.1_web.pdf>. Acesso em: 3 de fevereiro de 2014. 


\section{ANEXO}

\section{Matriz 1 - Origem e destino dos migrantes intrametropolitanos - RMF - 1986/1991 (Data fixa)}

\begin{tabular}{|c|c|c|c|c|c|c|c|c|c|c|c|c|c|c|c|}
\hline \multirow{2}{*}{ Origem em 1986} & \multicolumn{14}{|c|}{ Destino em 1991} & \multirow{2}{*}{$\begin{array}{l}\text { Total de } \\
\text { Emig. }\end{array}$} \\
\hline & Aquiraz & Cascavel & Caucaia & \begin{tabular}{|l|} 
Chorozinho \\
\end{tabular} & Eusébio & \begin{tabular}{|l|} 
Fortaleza \\
\end{tabular} & \begin{tabular}{|l|} 
Guaiuba \\
\end{tabular} & Horizonte & Maracanaú & Maranguape & Pacajus & \begin{tabular}{|l|} 
Pacatuba \\
\end{tabular} & Pindoretama & S.Gonç. do Amar. & \\
\hline Aquiraz & - & 32 & 149 & 0 & 161 & 904 & $\begin{array}{l}0 \\
\end{array}$ & 177 & 39 & 0 & 66 & 54 & 128 & 0 & 1.710 \\
\hline Cascavel & 333 & - & 69 & 391 & 0 & 1.279 & 0 & 47 & 39 & 33 & 194 & 93 & 85 & 0 & 2.563 \\
\hline \begin{tabular}{|l|} 
Caucaia \\
\end{tabular} & 216 & 21 & - & 0 & 78 & 2.185 & 80 & 0 & 478 & 244 & 9 & 234 & 7 & 375 & 3.927 \\
\hline Chorozinho & 4 & 107 & 10 & - & 50 & 258 & 0 & 0 & 82 & 0 & 385 & 0 & 29 & 0 & 925 \\
\hline Eusébio & 141 & 18 & 28 & 0 & - & 58 & 0 & 24 & 0 & 0 & 0 & 43 & 7 & 0 & 319 \\
\hline Fortaleza & 1.542 & 1.179 & 19.708 & 204 & 1.303 & - & 170 & 651 & 17.919 & 1.099 & 592 & 7.539 & 350 & 870 & 53.126 \\
\hline Guaiuba & 0 & 18 & 12 & 0 & 0 & 237 & - & 0 & 105 & 10 & 0 & 182 & 0 & 0 & 564 \\
\hline Horizonte & 68 & 0 & 8 & 63 & 0 & 122 & 17 & - & 5 & 0 & 394 & 0 & 0 & 0 & 677 \\
\hline Maracanaú & 22 & 0 & 276 & 0 & 31 & 579 & 77 & 0 & - & 177 & 0 & 642 & 0 & 62 & 1.866 \\
\hline Maranguape & 62 & 60 & 324 & 0 & 200 & 2.264 & 48 & 0 & 1.289 & - & 21 & 152 & 0 & 52 & 4.472 \\
\hline Pacajus & 36 & 240 & 54 & 91 & 0 & 769 & 31 & 113 & 287 & 0 & 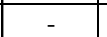 & 42 & 0 & 0 & 1.663 \\
\hline Pacatuba & 196 & 14 & 87 & 0 & 41 & 634 & 59 & 45 & 350 & 95 & 85 & - & 36 & 0 & 1.642 \\
\hline Pindoretama & 319 & 35 & 0 & 0 & 22 & 183 & 0 & 70 & 0 & 0 & 0 & 46 & - & 0 & 675 \\
\hline S. Gonç. do Ama & 54 & 0 & 319 & 0 & 0 & 1.070 & 0 & 0 & 0 & 0 & 0 & 29 & 0 & - & 1.472 \\
\hline Total de Imig. & 2.993 & 1.724 & 21.044 & 749 & 1.886 & 10.542 & 482 & 1.127 & 20.593 & 1.658 & 1.746 & 9.056 & 642 & 1.359 & 75.601 \\
\hline Saldo Migratório & 1.283 & -839 & 17.117 & -176 & 1.567 & -42584 & -82 & 450 & 18.727 & -2.814 & 83 & 7.414 & -33 & -113 & - \\
\hline
\end{tabular}

Fonte: Elaboração própria a partir dos microdados do Censo Demográfico de 1991 - IBGE

\section{Matriz 2 - Origem e destino dos migrantes intrametropolitanos - RMF - 1995/2000 (Data fixa)}

\begin{tabular}{|c|c|c|c|c|c|c|c|c|c|c|c|c|c|c|c|c|}
\hline \multirow[b]{2}{*}{ Origem em 1995} & \multicolumn{15}{|c|}{ Destino em 2000} & \multirow{2}{*}{$\begin{array}{c}\text { Total de } \\
\text { Emig. }\end{array}$} \\
\hline & Aquiraz & Cascavel & Caucaia & Chorozinho & Eusébio & Fortaleza & Guaiuba & \begin{tabular}{|l|} 
Horizonte \\
\end{tabular} & Itaitinga & Maracanau & Maranguape & Pacajus & Pacatuba & Pindoretema & S. Gonç. do Amar. & \\
\hline Aquiraz & - & 108 & \begin{tabular}{|l|l|} 
& 45 \\
\end{tabular} & 0 & 306 & 431 & 2 & 393 & 122 & \begin{tabular}{|l|}
21 \\
\end{tabular} & 92 & 54 & 16 & 201 & 41 & 1.832 \\
\hline Cascavel & 307 & - & 62 & 156 & 47 & 1.069 & 0 & 91 & 11 & 11 & 0 & 279 & 0 & 137 & 20 & 2.190 \\
\hline Caucaia & 124 & 32 & - & 0 & 63 & 1.694 & 6 & 86 & 48 & 678 & 177 & 0 & 158 & 12 & 235 & 3.313 \\
\hline Chorozinho & 8 & 33 & 21 & - & 0 & 381 & 0 & 471 & 11 & 0 & 0 & 614 & 0 & 0 & 0 & 1.539 \\
\hline Eusébio & 91 & 0 & 163 & 0 & - & 237 & 0 & 70 & 132 & 127 & 0 & 9 & 0 & 10 & 0 & 839 \\
\hline Fortaleza & 2.617 & 1.658 & 20.405 & 324 & 2.282 & - & 257 & 2.477 & 1.053 & 11.839 & 1.526 & 1.445 & 3.730 & 448 & 859 & 50.920 \\
\hline Guaiuba & 35 & 0 & 8 & 18 & 0 & 451 & - & 132 & 6 & 115 & 65 & 0 & 73 & 0 & 0 & 903 \\
\hline Horizonte & 51 & 0 & 0 & 8 & 28 & 290 & 19 & - & 43 & 43 & 0 & 135 & 0 & 0 & 0 & 617 \\
\hline Itaitinga & 92 & 10 & 0 & 20 & 31 & 172 & 0 & 38 & - & 69 & 51 & 26 & 53 & 0 & 0 & 562 \\
\hline Maracanau & 87 & 32 & 574 & 0 & 12 & 2.051 & 139 & 117 & 42 & - & 532 & 60 & 1.070 & 0 & 9 & 4.725 \\
\hline Maranguape & 84 & 0 & 300 & 0 & 78 & 1.343 & 102 & 66 & 0 & 856 & - & 10 & 31 & 15 & 0 & 2.885 \\
\hline Pacajus & 56 & 132 & 34 & 73 & 10 & 570 & 0 & 251 & 43 & 49 & 9 & & 6 & 7 & 0 & 1.240 \\
\hline Pacatuba & 40 & 11 & 63 & 0 & 65 & 403 & 77 & 54 & 49 & 306 & 0 & 9 & - & 0 & 57 & 1.134 \\
\hline Pindoretama & 142 & 116 & 11 & 0 & 17 & 170 & 0 & 9 & 0 & 0 & 11 & 0 & 0 & - & 0 & 476 \\
\hline S. Gonç. do Amar & 15 & 0 & 228 & 0 & 8 & 470 & 0 & 0 & 0 & 19 & 0 & 8 & 21 & 6 & - & 775 \\
\hline \begin{tabular}{|l|} 
Total de Imig. \\
\end{tabular} & 3.749 & 2.132 & 21.914 & 599 & 2.947 & 9.732 & 602 & 4.255 & 1.560 & 14.133 & 2.463 & 2.649 & 5.158 & 836 & 1.221 & 73.950 \\
\hline Saldo Migratório & 1.917 & -58 & 18.601 & -940 & 2.108 & -41.188 & -301 & 3.638 & 998 & 9.408 & -422 & 1.409 & 4.024 & 360 & 446 & \\
\hline
\end{tabular}

Fonte: Elaboração própria a partir dos microdados do Censo Demográfico 2000 - IBGE

\section{Matriz 3 - Origem e destino dos migrantes intrametropolitanos - RMF - 2005/2010 (Data fixa)}

\begin{tabular}{|c|c|c|c|c|c|c|c|c|c|c|c|c|c|c|c|c|}
\hline \multirow{2}{*}{ Origem em 2005} & \multicolumn{15}{|c|}{ Destino em 2010} & \multirow{2}{*}{$\begin{array}{l}\text { Total de } \\
\text { Emig. }\end{array}$} \\
\hline & Aquiraz & Cascavel & Caucaia & Chorozinho & Eusébio & \begin{tabular}{|l|} 
Fortaleza \\
\end{tabular} & Guaiuba & Horizonte & Itaitinga & Maracanau & Maranguape 1 & Pacajus & \begin{tabular}{|l|l} 
Pacatuba & F
\end{tabular} & Pindoretema & S. Gonç. do Amar. & \\
\hline Aquiraz & - & 252 & 91 & \begin{tabular}{r|}
23 \\
\end{tabular} & 243 & \begin{tabular}{|l|}
449 \\
\end{tabular} & $\begin{array}{r}0 \\
\end{array}$ & 396 & 184 & \begin{tabular}{|r|}
23 \\
\end{tabular} & 0 & 66 & \begin{tabular}{|r|}
0 \\
\end{tabular} & 248 & $\begin{array}{r}0 \\
\end{array}$ & 1.975 \\
\hline Cascavel & 111 & \begin{tabular}{l|l|}
- & \\
\end{tabular} & 100 & 32 & 14 & 520 & 0 & 152 & 22 & 70 & 0 & 253 & 0 & 249 & 28 & 1.551 \\
\hline Caucaia & 200 & 42 & & 19 & 16 & 2.134 & 0 & 66 & 85 & 578 & 81 & 52 & 67 & 43 & 545 & 3.928 \\
\hline Chorozinho & 26 & 124 & 0 & - & 11 & 205 & 0 & 115 & 0 & 35 & 0 & 801 & 0 & 13 & 0 & 1.330 \\
\hline Eusébio & 351 & 0 & 114 & 5 & - & 275 & 0 & 46 & 33 & 33 & 0 & 68 & 0 & 19 & 0 & 944 \\
\hline Fortaleza & 3.158 & 1.802 & 15.874 & 250 & 4.045 & - & 318 & 2.665 & 1.304 & 7.805 & 1.308 & 1.734 & 1.185 & 648 & 1.995 & 44.091 \\
\hline Guaiuba & 54 & 0 & 0 & 0 & 0 & 418 & -4 & 73 & 0 & 83 & 41 & 9 & 17 & 0 & 45 & 740 \\
\hline Horizonte & 187 & 29 & 41 & 23 & 133 & 544 & 0 & - & 31 & 42 & 37 & 309 & 0 & 20 & 0 & 1.396 \\
\hline Itaitinga & 95 & 0 & 66 & 0 & 95 & 326 & 0 & 215 & - & 6 & 0 & 59 & 129 & 0 & 11 & 1.002 \\
\hline Maracanau & 106 & 51 & 606 & 0 & 54 & 1.810 & 20 & 129 & 29 & - & 295 & 94 & 867 & 0 & 49 & 4.110 \\
\hline Maranguape & 119 & 0 & 209 & 0 & 0 & 916 & 74 & \begin{tabular}{c|}
57 \\
\end{tabular} & 31 & 831 & - & 33 & 45 & 13 & 26 & 2.354 \\
\hline Pacajus & 54 & 150 & 33 & 199 & 24 & 655 & 0 & 554 & 80 & 152 & 77 & \begin{tabular}{l|l}
- \\
\end{tabular} & 64 & 46 & 0 & 2.088 \\
\hline Pacatuba & 36 & 0 & 13 & 0 & 0 & 498 & 46 & 145 & 63 & 242 & 21 & 39 & \begin{tabular}{l|l}
- & \\
\end{tabular} & 0 & 27 & 1.130 \\
\hline Pindoretama & 96 & 133 & 14 & 5 & 44 & 159 & 0 & 84 & 0 & 0 & 0 & 0 & $68-$ & & 0 & 603 \\
\hline S. Gonç. do Amar. & 14 & 14 & 244 & 0 & 22 & 373 & 0 & 0 & 0 & 42 & 0 & 0 & 13 & 0 & - & 722 \\
\hline Total de Imig. & 4.607 & 2.597 & 17.405 & 556 & 4.701 & 9.282 & 458 & 4.697 & 1.862 & 9.942 & 1.860 & 3.517 & 2.455 & 1299 & 2.726 & 67.964 \\
\hline Saldo Migratório & 2.632 & 1.046 & 13.477 & -774 & 3.757 & -34.809 & -282 & 3.301 & 860 & 5.832 & -494 & 1.429 & 1.325 & $\begin{array}{l}696 \\
\end{array}$ & 2.004 & \\
\hline
\end{tabular}

Fonte: Elaboração própria a partir dos microdados do Censo Demográfico 2010 - IBGE 